\title{
Epitypification of Tilletia ehrhartae, a smut fungus with potential for nature conservation, biosecurity and biocontrol
}

\author{
Marcin Piątek • Matthias Lutz • Adriaana Jacobs • \\ Francis Villablanca $\cdot$ Alan R. Wood
}

Accepted: 1 May 2015 / Published online: 21 May 2015

(C) The Author(s) 2015. This article is published with open access at Springerlink.com

\begin{abstract}
Tilletia ehrhartae, a smut fungus infecting perennial veldtgrass Ehrharta calycina, is epitypified and characterized using the Consolidated Species Concept, including morphology, ecology (host plant) and rDNA sequences (ITS and LSU). Tilletia ehrhartae is native and endemic to the Cape Floral Kingdom (located entirely in South Africa), but it has also been introduced to the alien artificial range of Ehrharta calycina in Australia and California. This smut has already caused some biosecurity problems in Australia as its spores were found to contaminate harvested wheat seeds, leading to confusion with Karnal bunt of wheat
\end{abstract}

M. Piątek $(\bowtie)$

Department of Mycology, W. Szafer Institute of Botany, Polish Academy of Sciences, Lubicz 46, PL-31-512 Kraków, Poland

e-mail:m.piatek@botany.pl

M. Lutz

Plant Evolutionary Ecology, Institute of Evolution and Ecology, University of Tübingen, Auf der Morgenstelle 1, D-72076 Tübingen, Germany

\section{A. Jacobs}

National Collection of Fungi, ARC-Plant Protection Research Institute, P. Bag X134QueenswoodPretoria 0121, South Africa

F. Villablanca

Biological Sciences Department, California Polytechnic State University, San Luis Obispo, CA 93407, USA

A. R. Wood

ARC-Plant Protection Research Institute, P. Bag X5017,

Stellenbosch 7599, South Africa caused by Tilletia indica (which is absent in Australia), and therefore constituting a potential risk for Australian wheat export. The current global distribution of Tilletia ehrhartae, possible colonization history, and potential for nature conservation, biosecurity and biocontrol are discussed. The sequences generated in this work could serve as DNA barcodes to facilitate rapid identification of this important species.

Keywords Australia $\cdot$ California $\cdot$ Cape Floral Kingdom · South Africa · Epitype · Plant pathogens . DNA barcodes

\section{Introduction}

The plant pathogenic teliosporic smut fungi are predominantly distributed with host plants growing in natural ecosystems, especially different kinds of grasslands and savannas where the highest species diversity occurs. These species have been intensively studied with respect to their biodiversity and evolutionary significance (Vánky 2012). A number of smut fungi are however also important to different aspects of human life and economy, being devastating pathogens of cultivated crops or ornamental plants. The clear application of correct names for plant pathogens having an impact on plant production and the economy is of primary interest for phytopathologists (Crous 2005; Wingfield et al. 2012). However, morphology often does not provide sufficient resolution for an unambiguous identification of species. In recent years, application of molecular 
methods has revealed a considerable degree of cryptic species amongst plant pathogens (Shivas and Cai 2012). Thus, the combination of morphological, ecological and molecular characters are valuable for correct species identification. This polyphasic approach has often been used to differentiate fungal species including smuts (Lutz et al. 2008; Bauer et al. 2008; Piątek et al. 2012, 2013; Savchenko et al. 2013, 2014; Vasighzadeh et al. 2014), and it was recently named the Consolidated Species Concept (Quaedvlieg et al. 2014). Strictly defined species, with reference sequences deposited in public repositories (such as NCBI's GenBank), are essential for progress in plant pathology. The ideal situation is when the reference sequences are from type specimens, which is usually realized when a new species is described based on recently collected material, but is difficult for species described during historical times and when the original type materials are inappropriate for sequencing. That dilemma, however, may be abrogated by epitypification of known species, with reference sequences obtained from a recently collected specimen that serves as the epitype. Ideally, such epitypifications should include material collected on the same host plant and in the same geographical area from where the species was described (Hyde and Zhang 2008).

Karnal bunt of wheat caused by Tilletia indica is a disease with minor yield impact for wheat production but important economic losses could result from quarantine regulations and export restrictions from infected regions (Carris et al. 2006). Three smut fungi with quite similar morphology could impede correct identification of Tilletia indica, namely T. ehrhartae, T. horrida and T. walkeri (Carris et al. 2006). Notably, none of these important bunt pathogens have ITS sequences generated from type specimens (the ITS sequences of Tilletia walkeri in GenBank cannot be unequivocally linked to the type specimen). Tilletia ehrhartae, a species infecting perennial veldtgrass (Ehrharta calycina), is native and endemic to South Africa (Vánky 2012), but has been introduced to Australia and California. This smut has already caused some biosecurity problems in Australia as its spores were found to contaminate harvested wheat seeds, leading to confusion with Tilletia indica (which is absent in Australia), and therefore constituting a potential risk for Australian wheat export (Pascoe et al. 2005; Vánky and Shivas 2008; Wright 2012). All previously generated sequences deposited in GenBank (one ITS: AY770433, and one LSU: AY819013) are from specimens collected in Australia. The main constraint of these sequences is that they were generated from specimens collected outside South Africa, i.e., from where Tilletia ehrhartae was described as new to science and also from non-native range of the host plant, and therefore none of the respective specimens was an appropriate candidate to be designated as the epitype. Furthermore, it cannot entirely be excluded that, under different environmental conditions, some local, morphologically similar species jumped to Ehrharta calycina and that Australian (and Californian) specimens do not represent Tilletia ehrhartae. The Californian material was not sequenced so far.

This study aimed to epitypify Tilletia ehrhartae using recently collected material in South Africa, to provide a detailed morphological and molecular characterization of the epitype specimen, and to compare the epitype ITS and LSU sequences with those obtained from Australian and Californian specimens in order to confirm their conspecificity. Both the South African and Californian material are used to provide DNA barcodes, and to discuss the current distribution of Tilletia ehrhartae in its natural and introduced range.

\section{Materials and methods}

Morphological examination

Sori, spores, and sterile cells of the South African material were studied using dried herbarium material. The herbarium specimens are deposited in KRAM F, KR-M, and PREM. The material was examined by light microscopy (LM) and scanning electron microscopy (SEM). The species description and measurements are based on holotype and epitype specimens. For LM, small pieces of sori were mounted in $80 \%$ lactic acid, heated to boiling point and cooled, and then examined under a Nikon Eclipse 80i light microscope. LM micrographs were taken with a Nikon DS-Fil camera. Fifty spores and at least 10 sterile cells were measured from each of the holotype and epitype, at a magnification of $\times 1000$, using NIS-Elements BR 3.0 imaging software. Except for the walls of spores, the remaining measurements are adjusted to the nearest $0.5 \mu \mathrm{m}$. For SEM, spores and sterile cells were mounted on carbon tabs and fixed to an aluminium stub with double-sided transparent tape. The stubs were sputter-coated with carbon using a Cressington sputter-coater and viewed under a 
Hitachi S-4700 scanning electron microscope, with a working distance of ca. $12 \mathrm{~mm}$. SEM micrographs were taken in the Laboratory of Field Emission Scanning Electron Microscopy and Microanalysis at the Institute of Geological Sciences of Jagiellonian University, Kraków (Poland).

DNA extraction, PCR, and sequencing

Genomic DNA for the South African epitype was isolated directly from the herbarium specimen. The California sample is from a specimen in the frozen tissue collection (FC - 712) at California Polytechnic State University, San Luis Obispo, CA. For methods of isolation and crushing of fungal material, DNA extraction, amplification, purification of PCR products, sequencing, and processing of the raw data see Lutz et al. (2004). The California sample used slightly modified PCR conditions. Three $\mu$ l of DNA extract was amplified in a total volume of $25 \mu \mathrm{l}$ with $2.5 \mu \mathrm{l} 10 \mathrm{X}$ JumpStart REDTaq buffer (Sigma-Aldrich), $1 \mathrm{mM} \mathrm{MgCl}_{2}$, $200 \mu \mathrm{M}$ of each dNTP, $0.3 \mu \mathrm{M}$ primer concentration, and 0.5 units of Jumpstart RED Taq (Sigma-Aldrich). ITS 1 and ITS 2 regions of the rDNA, including the 5.8S rDNA, (ITS, about $730 \mathrm{bp}$ ) were amplified using the primer pair ITS1-F (Gardes and Bruns 1993) and ITS4 (White et al. 1990). The 5'-end of the nuclear large subunit ribosomal DNA (LSU, about 620 bp) was amplified using the primer pair NL1 and NL4 (O'Donnell 1993). Primers were used for both PCR and cycle sequencing. For amplification the annealing temperature was adjusted to $45^{\circ} \mathrm{C}$. DNA sequences determined for this study were deposited in GenBank [accession numbers (ITS/LSU): KJ728757/KJ728756, KP793094/ KP793093 for South African and Californian samples, respectively].

\section{Results}

The morphology of the recently collected material of Tilletia ehrhartae from South Africa matches exactly with the holotype of this species deposited in PREM. The former specimen is designated here as the epitype of Tilletia ehrhartae. The morphological characteristics of this smut are included in the species description and depicted in Figs. 1 and 2.

Tilletia ehrhartae P.H.B. Talbot, Bothalia 7 (1): 110 (1958) Figs. 1 and 2
Parasitic on Ehrharta calycina, infection systemic, infected culms dwarfed. Sori in all ovaries in the inflorescences, causing a moderate hypertrophy of the ovaries, ovoid to broadly fusiform, 2-7 $\mathrm{mm}$ long, $1.5-2 \mathrm{~mm}$ wide, partly or rarely completely hidden by the glumes, at first enclosed by a dirty green pericarp of host origin that in maturity ruptures irregularly exposing a blackish brown, granular powdery mass of spores mixed with sterile cells. Spores brown to chestnut-brown, rarely pale brown, regular in shape and size, globose or subglobose, (17.5-) 18.0-22.0 (-23.0) × 17.5-21.0 $\mu \mathrm{m}$ [av. $\pm \mathrm{SD}, 19.9 \pm 1.3 \times 19.3 \pm 1.1 \mu \mathrm{m}, n=50]$ for the epitype, (17.0-) 18.0-22.0 (-23.5) × 17.5-21.0 $\mu \mathrm{m}$ [av. $\pm \mathrm{SD}, 19.5 \pm 1.4 \times 19.3 \pm 1.1 \mu \mathrm{m}, n=50]$ for the holotype; wall evenly thick, ca. $0.5-1.0 \mu \mathrm{m}$, surface covered with dense, cylindrical or subpyramidal, blunt warts, 1.5$2.5 \mu \mathrm{m}$ long in the epitype and 1.6-3.3 $\mu \mathrm{m}$ long in the holotype, embedded in a thin mucilaginous, hyaline matrix (not exceeding the surface of warts), in surface view the warts appear as darker, irregularly polygonal areas when observed by LM, densely, bluntly conical when observed by SEM. Immature spores hyaline or subhyaline with developed ornamentation are observed between mature spores. Sterile cells hyaline, subhyaline to pale brown, subglobose, ovoid to broadly ellipsoidal, usually somewhat irregular, $14.0-27.0 \times 12.0-25.0 \mu \mathrm{m}$; wall evenly thick, indistinctly multilayered, 2.0-3.5 $(-5.0) \mu \mathrm{m}$, smooth as seen by LM and SEM.

Specimens examined South Africa, Western Cape Province, Clanwilliam District, Lambert's Bay, Nature Reserve, on Ehrharta calycina, 26 Oct. 1956, leg. R. Story 6006 (holotype PREM 41604, isotype BRIP: HUV 2278); Cape Town, Brackenfell, Bracken Nature Reserve, on Ehrharta calycina, Cape Flats Sand Fynbos, 5 Oct. 2013, leg. A.R. Wood 921 (epitype designated here PREM 60989, isoepitypes KRAM F-56818, KRM-0038199; MycoBank MBT201196; ITS sequence GenBank KJ728757, LSU sequence GenBank KJ728756). U.S.A., California, Pismo-OceanoNipomo-Guadalupe Dunes Complex, on Ehrharta calycina, 22 July 2010, leg. F. Villablanca (CPSU-FC 712, ITS sequence GenBank KP793094, LSU sequence GenBank KP793093).

Molecular characterization The ITS and LSU sequences from the South African (epitype) and Californian specimens of Tilletia ehrhartae were identical compared to the ITS and LSU sequences obtained from 
Fig. 1 Tilletia ehrhartae on Ehrharta calycina. a Infected plants of Ehrharta calycina in Bracken Nature Reserve, South Africa. $\mathbf{b}-\mathbf{c}$ Sori in the ovaries. Scale bars $=1 \mathrm{~mm}$

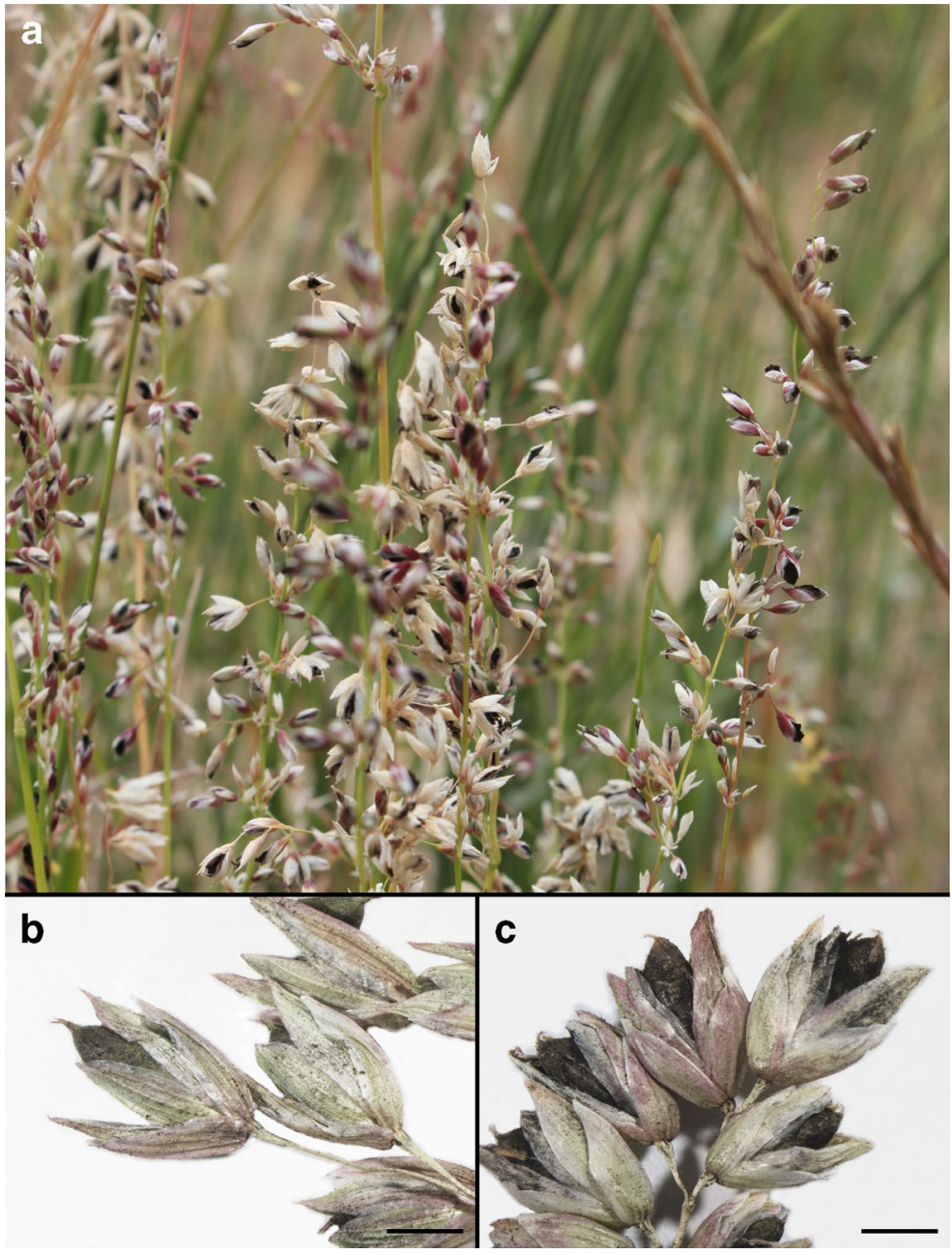

Australian specimens (ITS: AY770433 from BRIP 28392, Pascoe et al. 2005; LSU: AY819013 from BRIP: HUV 19754, Castlebury et al. 2005), confirming conspecificity of the South African, Californian, and Australian specimens. Based on a standard nucleotide BLAST search of NCBI's GenBank nucleotide database using BLASTN (Altschul et al. 1997), the closest hits, besides Tilletia ehrhartae, using the ITS were two sequences of Tilletia sp. on Megathyrsus maximus (Max score/E value: 930/0.0), T. barclayana (809/0.0), T. maclaganii (801/ 0.0), T. narayanaraoana (798/0.0), and T. horrida (771/ $0.0)$. Using the LSU the closest hits were Tilletia setariae (1063/0.0), two sequences of Tilletia sp. on Megathyrsus maximus (1054/0.0), two sequences of T. rugispora (1050/0.0), T. indica (1045/0.0), and T. barclayana (1045/0.0). The sequences (especially ITS sequences) generated in this work could serve as DNA barcodes for Tilletia ehrhartae. Additionally, the ITS sequence from the epitype of Tilletia ehrhartae is recommended to be deposited in the RefSeq Targeted Loci database (Schoch et al. 2014).

\section{Discussion}

This study provides a detailed morphological and molecular characterization of Tilletia ehrhartae based on the newly designated epitype specimen established to promote taxonomic stability and to build an unequivocal identity of this smut fungus. The species characterization follows the Consolidated Species Concept (Quaedvlieg et al. 2014). Additionally, this study provides the first molecular characterization of Californian 

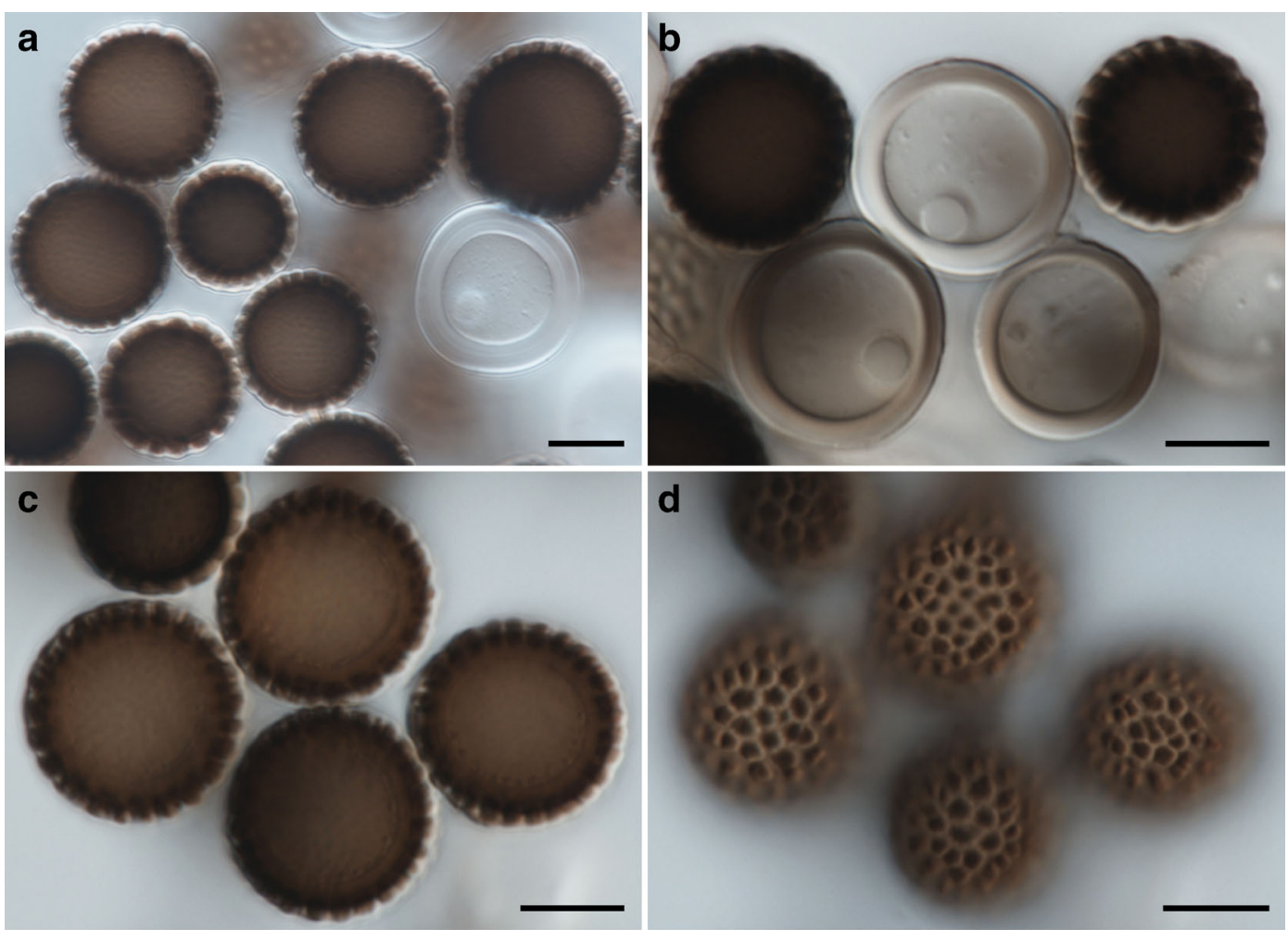
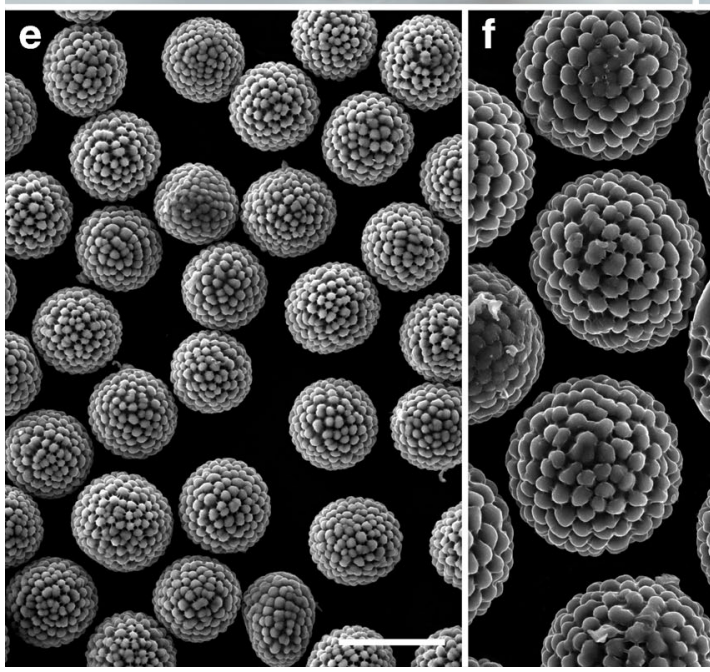

Fig. 2 Tilletia ehrhartae on Ehrharta calycina (KRAM F-56818). a-b Spores and sterile cells as seen by light microscopy. c-d Spores and sterile cells as seen by light microscopy, median and

material. Comparisons of the newly generated DNA sequences with available sequences deposited in GenBank confirmed con-specificity of the South African, Californian, and Australian specimens responsible for the bunt of Ehrharta calycina in these countries or states. Reference sequences (especially sequences of the ITS region that is a barcode marker for Fungi, Schoch
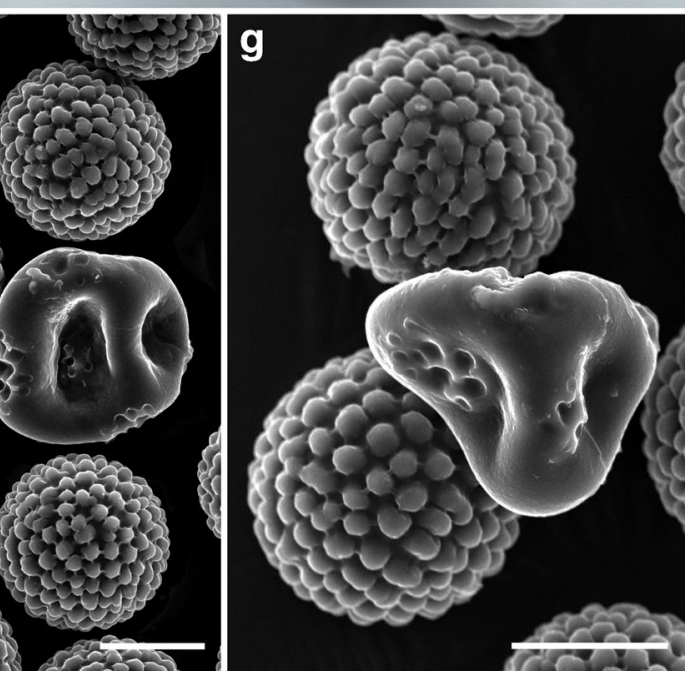

superficial views. e Spores as seen by scanning electron microscopy. $\mathbf{f}-\mathbf{g}$ Spores and sterile cells as seen by scanning electron microscopy. Scale bars $\mathbf{a}, \mathbf{b}, \mathbf{c}, \mathbf{d}=10 \mu \mathrm{m}, \mathbf{e}, \mathbf{f}=20 \mu \mathrm{m}, \mathbf{g}=10 \mu \mathrm{m}$

et al. 2012) generated from the South African (epitype) and Californian specimen are particularly valuable as molecular barcodes because the spores of Tilletia ehrhartae often contaminate wheat seeds without a clear connection to the appropriate host plant that hampers species identification exclusively on morphological characters. 
The proposed synonymy of Tilletia ehrhartae with T. rugispora suggested by Durán and Fischer (1961), but not supported by morphological differences (Vánky 2012), is additionally not supported by molecular data as comparison of available sequence data revealed a considerable genetic distance between both species: the LSU of the T. ehrhartae epitype differed in $14 \mathrm{bp}$ (2.27\%) compared to the available $T$. rugispora LSU sequences AY818982 (on Paspalum convexum, WSP 60775) and AY818983 (on P. plicatulum, BRIP: HUV 19147), the latter two sequences being identical.

Tilletia ehrhartae seems to be specific to Ehrharta calycina, a grass indigenous to South Africa, but introduced to Australia, New Zealand and California where it has become an alien invasive weed. Originally, Tilletia ehrhartae was described from infected ovaries of Ehrharta calycina collected in Lambert's Bay in the Western Cape Province of South Africa in 1956 (Talbot 1958). It was again found in South Africa in the Cape of Good Hope Nature Reserve (now part of Table Mountain National Park) in 1996 (Triebel 1998) and now in Bracken Nature Reserve, both also in the Western Cape Province, on the same host plant species (Fig. 3). These records undoubtedly represent the native range of Tilletia ehrhartae. In its native range, this species is one of a group of smut fungi endemic to the Cape Floral Kingdom (e.g., Vánky 1997, 1999, 2009; Roets et al. 2008, 2012; Curran et al. 2009), that are apparently scarce in this floristic region. The red data status of these fungi needs assessing, and if necessary appropriate conservation measures introduced.

Tilletia ehrhartae is widespread in the alien range of Ehrharta calycina in Australia (Western Australia, South Australia and Victoria) (Vánky and Shivas 2008) (Fig. 3) where it is often found on veldtgrass growing on roadsides close to wheat yields, contaminating harvested wheat seeds, and as mentioned above on one occasion its misidentification as $T$. indica resulted in the rejection of a shipment of wheat by the importing country (Pascoe et al. 2005; Vánky and Shivas 2008; Wright 2012). This led Australian phytopathologists to develop identification protocols for Tilletia ehrhartae, using detailed morphological characters and the rDNA ITS sequence obtained from one Australian specimen (Pascoe et al. 2005; Wright 2012). Furthermore, Tan et al. (2009) established a fluorescent PCR assay for the detection of five Tilletia species, including T. ehrhartae, which could infest or contaminate wheat grains. With the present confirmation of the identity of that Australian specimen, through direct comparison of its ITS sequence (AY770433) with the same obtained from the epitype originating from the type locality area in South Africa, the developed identification procedures become fully validated, complementary and workable.

Tilletia ehrhartae is also potentially widespread in the alien range of Ehrharta calycina in California (Overman et al. 2010) (Fig. 3). For example, in California's central coast Tilletia ehrhartae occurs at high

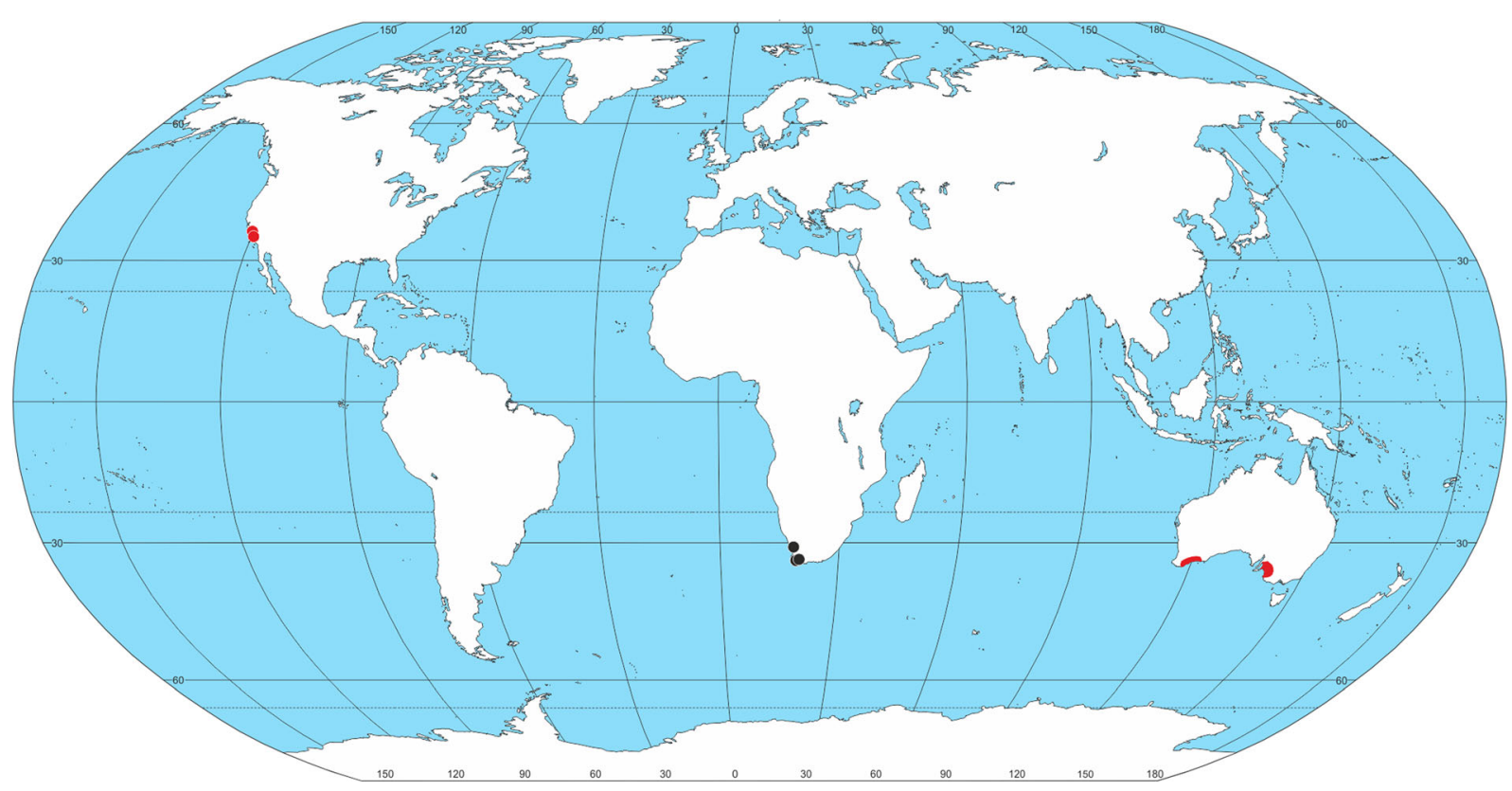

Fig. 3 Geographical distribution of Tilletia ehrhartae: black circles=native range, red circles and areas=alien introduced range 
frequency on veldtgrass in at least two disjunct populations (Central California coastal dune complexes of Los Osos, and Guadalupe-Nipomo) (Overman et al. 2010). In California, veldtgrass is regarded as an undesirable species in an explosive stage of invasion (Bossard et al. 2000) and is assigned to the highest impact/invasion category by the California Invasive Plant Council (http://www.cal-ipc.org). This category is reserved for species that have severe ecological impacts and potential for broad dispersal and establishment. That the high level of host specificity of Tilletia ehrhartae makes this smut a potential biocontrol agent for Ehrharta calycina has been suggested for Ehrharta calycina in general (Vishunavat 2013), and for the Californian populations in particular (Overman et al. 2010). Interestingly, though Tilletia ehrhartae is parasitic on Ehrharta calycina, and the infection is systemic, sori are only present in infected culms (dwarfed), and not all culms are infected (Overman et al. 2010). In addition, it is known that herbivory by a California native species (black-tailed jackrabbits Lepus californicus), significantly reduced the height, shoot production, fecundity and above-ground biomass of veldtgrass (Cushman et al. 2011). Future detailed studies are needed to determine the relative success of Tilletia ehrhartae in controlling the spread of Ehrharta calycina in Australia and California. It appears that control strategies might be particularly successful if they are multifaceted.

The pathways of introduction of Tilletia ehrhartae to Australia, dating back to when it was first discovered in 1981, is unknown. Veldtgrass was first reported in California in 1929, and known to have been imported as seed from Australia (Love 1948, cited in Pickart 2000). None of the other known co-evolved pathogens of Ehrharta calycina, including Ustilago sladenii (Vánky 2012), and Uromyces quaggafonteinus (Mennicken and Oberwinkler 2004; Berndt and Wood 2012) have reached Australia and California. This may imply that the introduction of Tilletia ehrhartae to Australia had been realized via infected seeds and occurred much earlier than 1981. Smutted seed is a very plausible source of introduction of Tilletia ehrhartae from Australia to California, and would imply that Tilletia ehrhartae was present in Australia as early as 1929.

Acknowledgments We thank Anna Łatkiewicz (Kraków, Poland) for her help with SEM pictures. Financial support for Marcin Piatek was provided by the National Science Centre (NCN) of Poland (project no. N N303 414037 for the years 2009-2014).
Compliance with Ethical Standards The authors declare that this work complies to the Ethical Standards of the journal, and that they have no conflict of interest.

Open Access This article is distributed under the terms of the Creative Commons Attribution 4.0 International License (http:// creativecommons.org/licenses/by/4.0/), which permits unrestricted use, distribution, and reproduction in any medium, provided you give appropriate credit to the original author(s) and the source, provide a link to the Creative Commons license, and indicate if changes were made.

\section{References}

Altschul, S. F., Madden, T. L., Schäffer, A. A., Zhang, J., Zhang, Z., Miller, W., \& Lipman, D. J. (1997). Gapped BLAST and PSI-BLAST: a new generation of protein database search programs. Nucleic Acids Research, 25, 3389-3402.

Bauer, R., Lutz, M., Begerow, D., Piątek, M., Vánky, K., Bacigálová, K., \& Oberwinkler, F. (2008). Anther smut fungi on monocots. Mycological Research, 112, 1297-1306.

Berndt, R., \& Wood, A. R. (2012). Additions to the rust fungi of South Africa. Mycological Progress, 11, 483-497.

Bossard, C. C., Randall, J. M., \& Hoshovsky, M. C. (Eds.). (2000). Invasive plants of California's Wildlands. Berkeley: University of California Press.

Carris, L. M., Castlebury, L. A., \& Goates, B. J. (2006). Nonsystemic bunt fungi-Tilletia indica and Tilletia horrida; a review of history, systematics and biology. Annual Review of Phytopathology, 44, 113-133.

Castlebury, L. A., Carris, L. M., \& Vánky, K. (2005). Phylogenetic analysis of Tilletia and allied genera in order Tilletiales (Ustilaginomycetes; Exobasidiomycetidae) based on large subunit nuclear rDNA sequences. Mycologia, 97, 888-900.

Crous, P. W. (2005). Plant pathology is lost without taxonomy. Outlooks on Pest Management, 16, 119-123.

Curran, H. R., Roets, F., \& Dreyer, L. L. (2009). Anther-smut fungal infection of South African Oxalis species: spatial distribution patterns and impacts on host fecundity. South African Journal of Botany, 75, 807-815.

Cushman, J., Lortie, C. J., \& Christian, C. E. (2011). Native herbivores and plant facilitation mediate the performance and distribution of an invasive exotic grass. Journal of Ecology, 99(2), 524-531.

Durán, R., \& Fischer, G. W. (1961). The genus Tilletia. Washington: Washington State University.

Gardes, M., \& Bruns, T. D. (1993). ITS primers with enhanced specificity for basidiomycetes - application to the identification of mycorrhizae and rusts. Molecular Ecology, 2, 113118.

Hyde, K. D., \& Zhang, Y. (2008). Epitypification: should we epitypify? Journal of Zhejiang University. Science. B, 9, 842-846.

Love, R. M. (1948). Eight new plants developed for California ranges. California Agriculture, 2, 7.

Lutz, M., Bauer, R., Begerow, D., Oberwinkler, F., \& Triebel, D. (2004). Tuberculina, rust relatives attack rusts. Mycologia, 96, 614-626. 
Lutz, M., Piątek, M., Kemler, M., Chlebicki, A., \& Oberwinkler, F. (2008). Anther smuts of Caryophyllaceae: molecular analyses reveal further new species. Mycological Research, 112, $1280-1296$.

Mennicken, M., \& Oberwinkler, F. (2004). A contribution to the rust flora (Uredinales) of southern Africa, with an emphasis on South Africa. Mycotaxon, 90, 1-28.

O’Donnell, K. L. (1993). Fusarium and its near relatives. In D. R. Reynolds \& J. W. Taylor (Eds.), The fungal holomorph: mitotic, meiotic and pleomorphic speciation in fungal systematics (pp. 225-233). Wallingford: CAB International.

Overman, B., Light, F., \& Villablanca, F. (2010). A seed infecting fungus (Tilletia ehrhartae) could provide a partial biological control mechanism for invasive veldt grass (Ehrharta calycina). Star Program. http://digitalcommons.calpoly.edu/ star/30/. Assessed 3 June 2014

Pascoe, I. G., Priest, M. J., Shivas, R. G., \& Cunnington, J. H. (2005). Ustilospores of Tilletia ehrhartae, a smut of Ehrharta calycina, are common contaminants of Australian wheat grain, and a potential source of confusion with Tilletia indica, the cause of Karnal bunt of wheat. Plant Pathology, 54, 161-168.

Piątek, M., Lutz, M., Ronikier, A., Kemler, M., \& Świderska-Burek, U. (2012). Microbotryum heliospermae, a new anther smut fungus parasitic on Heliosperma pusillum in the mountains of the European Alpine System. Fungal Biology, 116, 185-195.

Piątek, M., Lutz, M., \& Chater, A. O. (2013). Cryptic diversity in the Antherospora vaillantii complex on Muscari species. IMA Fungus, 4, 5-19.

Pickart, A. J. (2000). Ehrharta calycina, Ehrharta erecta, and Ehrharta longiflora. In C. C. Bossard, J. M. Randall, \& M. C. Hoshovsky (Eds.), Invasive plants of California's Wildlands (pp. 164-170). Berkeley: University of California Press Berkeley.

Quaedvlieg, W., Binder, M., Groenewald, J. Z., Summerell, B. A., Carnegie, A. J., Burgess, T. I., \& Crous, P. W. (2014). Introducing the Consolidated Species Concept to resolve species in the Teratosphaeriaceae. Persoonia, 33, 1- 40.

Roets, F., Dreyer, L. L., Wingfield, M. J., \& Begerow, D. (2008). Thecaphora capensis sp. nov., an unusual new anther smut on Oxalis in South Africa. Persoonia, 21, 147-152.

Roets, F., Curran, H. R., \& Dreyer, L. L. (2012). Morphological and reproductive consequences of an anther smut fungus on Oxalis. Sydowia, 64, 267-280.

Savchenko, K. G., Lutz, M., Piątek, M., Heluta, V. P., \& Nevo, E. (2013). Anthracoidea caricis-meadii is a new North American smut fungus on Carex sect. Paniceae. Mycologia, 105, 181-193.

Savchenko, K. G., Carris, L., Castlebury, L. A., Heluta, V., Wasser, S., \& Nevo, E. (2014). Revision of Entyloma (Entylomatales, Exobasidiomycetes) on Eryngium. Mycologia, 106, 797-810.

Schoch, C. L., Seifert, K. A., Huhndorf, S., Robert, V., Spouge, J. L., Levesque, C. A., Chen, W., \& Fungal Barcoding Consortium. (2012). Nuclear ribosomal internal transcribed spacer (ITS) region as a universal DNA barcode marker for Fungi. Proceedings of the National Academy of Sciences USA, 109, 6241-6246.

Schoch, C. L., Robbertse, B., Robert, V., Vu, D., Cardinali, G., Irinyi, L., Meyer, W., Nilsson, R. H., Hughes, K., Miller, A. N., Kirk, P. M., Abarenkov, K., Aime, M. C., Ariyawansa, H. A., Bidartondo, M., Boekhout, T., Buyck, B., Cai, Q., Chen, J., Crespo, A., Crous, P. W., Damm, U., De Beer, Z. W., Dentinger, B. T. M., Divakar, P. K., Dueñas, M., Feau, N.,
Fliegerova, K., García, M. A., Ge, Z. W., Griffith, G. W., Groenewald, J. Z., Groenewald, M., Grube, M., Gryzenhout, M., Gueidan, C., Guo, L., Hambleton, S., Hamelin, R., Hansen, K., Hofstetter, V., Hong, S. B., Houbraken, J., Hyde, K. D., Inderbitzin, P., Johnston, P. R., Karunarathna, S. C., Kõljalg, U., Kovács, G. M., Kraichak, E., Krizsan, K., Kurtzman, C. P., Larsson, K. H., Leavitt, S., Letcher, P. M., Liimatainen, K., Liu, J. K., Lodge, D. J., Luangsaard, J. J., Lumbsch, H. T., Maharachchikumbura, S. S. N., Manamgoda, D., Martín, M. P., Minnis, A. M., Moncalvo, J. M., Mulè, G., Nakasone, K. K., Niskanen, T., Olariaga, I., Papp, T., Petkovits, T., Pino-Bodas, R., Powell, M. J., Raja, H. A., Redecker, D., Sarmiento-Ramirez, J. M., Seifert, K. A., Shrestha, B., Stenroos, S., Stielow, B., Suh, S. O., Tanaka, K., Tedersoo, L., Tellería, M. T., Udayanga, D., Untereiner, W. A., Uribeondo, J. D., Subbarao, K. V., Vágvölgyi, C., Visagie, C., Voigt, K., Walker, D. M., Weir, B. S., Weiß, M., Wijayawardene, N. N., Wingfield, M. J., Xu, J. P., Yang, Z. L., Zhang, N., Zhuang, W. Y., \& Federhen, S. (2014). Finding needles in haystacks: linking scientific names, reference specimens and molecular data for Fungi. Database, 2014, bau061.

Shivas, R. G., \& Cai, L. (2012). Cryptic fungal species unmasked. Microbiology Australia, 33, 36-37.

Talbot, P. H. B. (1958). New and interesting records of South African fungi. Part III. Bothalia, 7, 109-111.

Tan, M. K., Ghalayini, A., Sharma, I., Yi, J. P., Shivas, R., Priest, M., \& Wright, D. (2009). A one-tube fluorescent assay for the quarantine detection and identification of Tilletia indica and other grass bunts in wheat. Australasian Plant Pathology, 38, 101-109.

Triebel, D. (1998). Microfungi exsiccati. Fasc. 11-14 (no. 251350). Arnoldia, 15, 1-43.

Vánky, K. (1997). Taxonomical studies on Ustilaginales. XVII. Mycotaxon, 65, 159-182.

Vánky, K. (1999). New smut fungi from South Africa. Mycotaxon, $70,17-34$.

Vánky, K. (2009). Taxonomic studies on Ustilaginomycetes - 29. Mycotaxon, 110, 289-324.

Vánky, K. (2012). Smut fungi of the world. St Paul: APS Press.

Vánky, K., \& Shivas, R. G. (2008). Fungi of Australia: The smut fungi. Canberra: ABRS \& CSIRO Publishing.

Vasighzadeh, A., Zafari, D., Selçuk, F., Hüseyin, E., Kurşat, M., Lutz, M., \& Piatek, M. (2014). Discovery of Thecaphora schwarzmaniana on Rheum ribes in Iran and Turkey: implications for the diversity and phylogeny of leaf smuts on rhubarbs. Mycological Progress, 13, 881-892.

Vishunavat, K. (2013). Smut fungi: potential pathogens and biocontrol agents. Centre of Advanced Faculty Training in Plant Pathology, 131-135.

White, T. J., Bruns, T., Lee, S., \& Taylor, J. (1990). Amplification and direct sequencing of fungal ribosomal RNA genes for phylogenetics. In M. A. Innis, D. H. Gelfand, J. J. Sninsky, \& T. J. White (Eds.), PCR protocols, a guide to methods and applications (pp. 315-322). San Diego: Academic.

Wingfield, M. J., de Beer, Z. W., Slippers, B., Wingfield, B. D., Groenewald, J. Z., Lombard, L., \& Crous, P. W. (2012). One fungus, one name promotes progressive plant pathology. Molecular Plant Pathology, 13, 604-613.

Wright, D. (2012). How the misidentification of a pathogen can cause an emergency response - a real life case study of an Australian grain export incident. Microbiology Australia, 33, 29-30. 